timber, and appearance of new types of infection in tobacco due to certain importations from Africa. Combating insect pests by cleanliness and rigorous control of storage conditions may suffice with materials initially sound, but is inadequate with materials imported in a highly infected condition. Work on this subject is being carried out at the Biological Field Station at Slough. Destruction by heat has been employed against wood-boring insects. Low temperatures are used in the tobacco trade; the resistance depends on the rate of cooling, and improved results have been obtained by a second cooling after an intermediate warming. Studies of the insecticidal action of some inert powders have given promising results; the action appears to be due to withdrawal of moisture. In discussing chemical insecticides that act in vapour form, Prof. Munro directed attention to the influence of various factors, such as temperature, and inequalities of distribution, and gave some results obtained in studying them. Investigations are in progress to elucidate the mechanism of insecticidal action and so to ascertain what properties are necessary in an insecticide to enable it to penetrate the epicuticle and cell-walls of an insect and upset the normal processes within.

\section{National Astrophysical Observatory of Mexico}

A NUMBER of distinguished scientific men from both North and South America took part in the InterAmerican Scientific Conference held in Mexico during February 15-26, on the occasion of the dedication of the new National Astrophysical Observatory of Mexico. President Manuel Avila Camacho, of Mexico, in issuing invitations to the conference, said : "The purpose of the Mexican Government is to contribute to the maintenance, in the American continent, of the progress of science and culture, and thus counteract as much as possible, the paralysation of scientific and cultural activities in the countries devastated by war". The new Observatory is situated on land provided by the Government of the State of Puebla, near a small town of Aztec origin called Tonanzintla, about 80 miles east of Mexico City. Under the direction of Prof. L. E. Erro, observations of the southern Milky Way will be made with a 24-30-in. Schmidt camera, the most powerful telescope in the tropics. This instrument will be similar to the Jewett telescope at Harvard Observatory, and its mounting is at present under construction in the Harvard shops. Its location in lat. $19^{\circ}$ is of great importance for studies of the southern skies, which are inaccessible to instruments farther north. The climate is excellent for observation, especially during the winter. The programme of the Observatory includes variable-star studies, and observations of meteors and the sun.

\section{Carnegie Trust for the Universities of Scotland}

THe fortieth annual report of the Carnegie Trust for the Universities of Scotland covers the academic year 1940-41, and includes details of the interim distribution of grants, the endowment of postgraduate study and research, assistance to students and an abstract of financial accounts for the year ended September 30, 1941 (Edinburgh: Carnegie Trust for the Universities of Scotland). Of the three who were elected to fellowships at the beginning of the year, two are still working in universities, and of the nine awarded senior scholarships, five (of whom four were women) completed the session's work. Of the forty-five scholars elected at the beginning of 1940-41, nineteen resigned immediately upon appointment or requested that their scholarships be suspended on account of war service. Of the thirty-five fellows, senior scholars and scholars elected in July 1941, thirteen have similarly asked that their awards be held in suspense, while three others were unable to accept owing to war work.

Reference is made in the course of the report to Dr. Webster's and Mrs. Hickie's work on the synthesis of compounds of possible value as anti-malarials, and to R. R. Coats's investigation on the interconversion of aromatic sulphonic acids and sulphones and on syntheses of sesquiterpene derivatives. J. Forrest has synthesized certain complex hydrocarbons and thrown much light on the reactions of fluorene, while A. B. Grant's work on the chitin of crab-shell has advanced our knowledge of chitose. Mention is also made of the work of Dr. W. Tebrich and Dr. J. M. Robson on the degree of penetration of sulphonamide compounds into the ocular tissues of rabbits when they are superficially deposited on the eye (see NATURe, Dec. 6, 1941, p. 695) and of Dr. J. D. Loudon's work on the mutual effect of substituent groups in benzene derivatives. The decrease in the assistance to students, amounting to 171 beneficiaries, was mainly among male students in the faculties of arts, law and divinity.

\section{Biological Research in China}

THE latest issue of Sinensia (2, No. 5-6, September, 1940) that has come to hand will be found an encouraging record of good work from the National Institute of Zoology and Botany, Academia Sinica, Peipah, Szechuan (China). With one exception the twelve contributions that go to make up the issue are the work of Chinese investigators. From the zoological point of view the most important papers are by Sicien H. Chen on leaf-beetles (Family Chrysomelidæ). This author proposes to raise the six sub-families that form this group to the status of separate families. This change implies that each of these families would become of the same taxonomic significance as the well-established families Cerambycidæ and Bruchidæ in the superfamily Phytophaga. In a second contribution the same author contributes extensive "Notes on Chinese Eumolpidæ", which deal with their classification and include descriptions of a number of new species. From the botanical side S. H. Ou's "Phycomycetes of China" (II) is a notable and well-illustrated paper. S.C. Teng's "Studies on Chinese Timber Trees in reference to Forest Management" (I) is a timely investigation now that the forests of China have come to a stage when they require systematic management.

\section{Universities' Federation for Animal Welfare}

THe fifteenth annual report of the Universities' Federation for Animal Welfare (UFAW) reports continued activities in its educational and research work; but as few students of the University of London are now in London college activities have been temporarily discontinued. More than six thousand copies of the Federation's new natural history lecturettes have been contributed at cost price to local education authorities. Much work is being done on the humane side of mole- and rabbittrapping, and authenticated information is being 